\title{
Analisis Diksi, Gaya Bahasa, dan Citraan dalam Empat Cerita Anak Indonesia Karya Murti Bunanta
}

\author{
Roy Raja Sukmanta Meliala, Sahid Teguh Widodo, Slamet Subiyantoro \\ FKIP Pascasarjana, Universitas Sebelas Maret \\ royrajasukmanta@gmail.com
}

\begin{abstract}
How to cite (in APA Style): Meliala, R.R.S., Widodo, S.T., \& Subiyantoro, S. (2018). Analisis diksi, gaya bahasa, dan citraan dalam empat cerita anak Indonesia karya Murti Bunanta. Jurnal Pendidikan Bahasa dan Sastra, 18(1), 95-105, doi: 10.17509/bs_jpbsp.v18i1.12149
\end{abstract}

Article History: Received (September 24, 2017); Revised (January 13, 2018); Accepted (March 27, 2018).

Journal homepage: http://ejournal.upi.edu./index.php/BS_JPBSP

\begin{abstract}
Abstrak: Penelitian ini meneliti empat cerita anak Indonesia Si Bungsu Katak, Si Molek, Masarasenani dan Matahari, dan Si Kecil karya Murti Bunanta. Cerita-cerita anak ini berasal dari berbagai daerah di Indonesia tetapi memiliki kesamaan dan perbedaan di setiap ceritanya. Metode deskriptif analisis ini menggunakan pendekatan stilistika yang mementingkan kesatuan konstruksi cerita dengan tema yang disampaikan. Elemen yang diperhatikan dan diperiksa adalah diksi, gayabahasa, dan citraan. Hasil dari penelitian ini adalah diksi yang dominan terlihat pada kata denotasi dengan jumlah 49 data atau presentase 53,85\%. Gaya bahasa yang dominan dapat terlihat pada gaya bahasa asidenton dengan jumlah 16 data atau presentase $25,8 \%$. Citraan yang dominan atau banyak dapat terlihat pada citraan penglihatan dengan jumlah 27 data atau presentase 36,99\%.
\end{abstract}

Kata kunci: cerita anak, Murti Bunanta, stilistika

\section{Diction Analysis, Style and Imagery of Four Stories of Indonesian Children by Murti Bunanta}

\begin{abstract}
This research examines four stories of Indonesian children "The Youngest Frog, Si Molek, Masarasenani and The Sun, and also Tiny Boy" by Murti Bunanta. These children's stories come from different region in Indonesia but have similarities and differences in each story. This descriptive analysis uses a stylistic approach that emphasizes the unity of story construction with the theme presented. Elements that are considered and checked are diction, style, and imagery. The result showed is the dominant diction can be seen in denotation with 49 data or 53.85 percentage. The dominant language style can be seen in asidenton language with 16 data or 25.8 percentage. The dominant or multiple images can be seen in visual images with 27 data or 36.99 percentage.
\end{abstract}

Keywords: children story, Murti Bunanta, stylistic 


\section{PENDAHULUAN}

Awal masa anak-anak diakui sebagai tahap yang unik dalam siklus kehidupan manusia dengan demikian ada kebutuhan untuk memastikan anak-anak mendapatkan pendidikan yang sesuai. Salah satu faktor yang mempergaruhi pendidikan anak adalah mutu bacaan yang diperoleh oleh anak-anak. Hal ini harus didukung dengan bacaan anak yang baik dan karya sastra merupakan salah satu media yang bisa digunakan untuk menilai bacaan anak yang baik.

Karya sastra merupakan hasil ciptaan manusia yang mengekspresikan pikiran, gagasan, pemahaman, dan tanggapan perasaan penciptanya tentang hakikat kehidupan dengan menggunakan bahasa yang imajinatif dan emosional (Nurgiyantoro, 2007,p. 2). Karya sastra tercipta melalui perenungan yang mendalam dengan tujuan untuk dinikmati, dipahami, dan diilhami oleh masyarakat. Sastra anak merupakan salah satu genre dalam karya sastra.

Hunt (dalam Nurgiyantoro, 2007,p. 26) mendefenisikan sastra anak dengan bertolak dari kebutuhan anak. Dia mengemukakan bahwa sastra anak dapat didefinisikan sebagai buku bacaan yang dibaca oleh anak, yang secara khusus cocok untuk, dan yang secara khusus pula memuaskan sekelompok anggota yang kini disebut sebagai anak-anak. Secara teoritis, sastra anak adalah sastra yang dibaca anak-anak "dengan bimbingan dan pengarahan anggota dewasa suatu masyarakat, sedang penulisannya juga dilakukan oleh orang dewasa" (Davis 1967 dalam Sarumpaet, 1976,p. 23). Dalam penelitian ini penulis mengangkat buku-buku karya Murti Bunanta yang berjudul "Si Bungsu Katak, Si Molek, Masarasenani dan Matahari, dan Si Kecil'.

Murti Bunanta adalah Doktor pertama dari Universitas Indonesia yang meneliti sastra anak-anak sebagai topik disertasi. Penelitian mengenai sastra anak-anak sudah dirintisnya sejak mengambil Sarjana Sastra dan Gelar Magister, juga di Universitas Indonesia. Selain menulis dua buku mengenai Literatur Anak pada tahun 1997 dan 2004, Murti Bunanta juga menulis buku untuk anak. Bukunya yang pertama berjudul Si Bungsu Katak (1998) (dwibahasa - Indonesia dan Inggris) mendapat hadiah internasional dari Polandia, The Janusz. Korzake International Literary Prize. Pada tahun yang sama, Murti Bunanta juga menerima Piagam Penghargaan dari Menteri Pariwisata, Seni dan Budaya Republik. Indonesia, Bapak Marzuki Usman (1998). Empat puluh dua buku lainnya telah terbit tahun 2001, 2004, 2005, 2006, 2007, 2008, dan 2009. Pada tahun 2003 terbit pula karyanya berjudul Indonesian Folktales berupa kumpulan cerita rakyat dalam bahasa Inggris untuk penerbit Amerika. Tahun 2013, bukunya yang berjudul The Tiny Boy and Other Tales from Indonesia diterbitkan di Kanada oleh Penerbit Groundwood.

Penelitian ini mengangkat empat (4) buku yang dituliskan oleh Murti Bunanta. Buku pertama Si Bungsu Katak (1998) cerita rakyat ini berasal dari kepulauan Kei yang terletak di Maluku Tenggara merupakan buku sastra anak (dwibahasa - Indonesia dan Inggris) yang ditulis oleh Murti Bunanta, buku ini mendapatkan hadiah internasional dari Poland, The Janusz, Korzcak International Literary Prize. Kedua buku Si Molek (2001) dongeng ini berasal dari Riau, ketiga Masarasenani dan Matahari (2001) cerita rakyat ini berasal dari papua, dan buku keempat Si Kecil (2001) cerita ini berasal dari Sulawesi Selatan, mendapatkan penghargaan dalam USBBY Outstanding International Books (OIB) List 2014 di Amerika. Alasan peneliti mengangkat empat buku tersebut adalah untuk melihat gaya penulisan seorang Murti Bunanta, persamaan dan perbedaan dalam setiap cerita anak, dan mewakili 24 judul buku yang tergabung dalam antologi Seri Folklor Anak. Keempat cerita anak ini diteliti menggunakan pendekatan stilistika dengan berfokus pada diksi, gaya bahasa, dan citraan.

Stilistika menurut Satoto (2012,p.35) bahwa style atau gaya merupakan cara yang khas dipergunakan oleh seseorang untuk mengutarakan atau mengungkapkan diri gaya pribadi. Menurut Ratna (2016,p.3) stilistika (stylistic) adalah ilmu tentang gaya, sedangkan stil (style) secara umum sebagaimana akan dibicarakan secara lebih luas pada bagian 
berikut adalah cara-cara yang khas, bagaimana segala sesuatu diungkapkan dengan cara tertentu, sehingga tujuan yang dinaksudkan dapat dicapai secara maksimal. Gaya adalah ciri-ciri, standar bahasa, dan cara ekspresi. Berdasarkan beberapa pendapat di atas, maka dapat diartikan bahwa stilistika merupakan cabang kajian ilmu sastra yang mempelajari pemanfaatan bahasa (gaya bahasa), gaya seorang pengarang yang secara khas tertuang dalam karyanya baik novel, puisi, maupun cerpen. Kajian ilmu ini untuk menerangkan fungsi artistik dan maknanya dalam mencari efek-efek yang ditimbulkan. Mengenai stilistika yang pernah digunakan pernah dibahas dalam beberapa penelitian sebelumnya.

Penelitian yang dilakukan oleh Chen (2013,p. 598) dengan judul Analysis on Three Versions of if by Life You Were Deceived from Perspectiive of Stylistics dilakukan untuk membantu perbedaan bahasa puisi dalam Rusia, Inggris, dan China supaya lebih jelas serta untuk mengkomparasikan dua versi terjamahan yang asli. Puisi tersebut dianalisis melalui perspektif gaya bahasa yang mencakup leksikal, irama, sajak, dan pola kalimat. Adapun penelitian yang dilakukan oleh Yeibo (2012) yang berjudul Figuratif Language and Stylistic Function J. P. ClarkBekederemo's Poetry menyebutkan bahwa bahasa kiasan sebagai penanda semantik dalam teks, yang mana membantu seniman sastra meraih estetika kesusastraan. Penelitian ini menitikberatkan pada hubungan tema dan figuratif language karya sastra. Lebih lanjut, Yeibo menyatakan bahwa kajian stilistika secara umum berhubungan dengan pemakaian bahasa figuratif yang berguna untuk menciptakan efek estetik. Penelitian Galita (2011) dengan judul A Pragma-Stylistic Approach on Deixis menggabungkan pendekatan stilistika dan pragmatik. Dalam penelitian Galita yang dianalisis adalah semua bahasa yang mencakup sarana ekspresi meliputi fonetis, morfologis, sintaksis, leksikal, dan semantik. Sedangkan, pendekatan pragmatik memfokuskan pada suasana hati pemakai bahasa pada waktu dan tempat serta hal-hal lain yang dapat mempengaruhi proses komunikasi.

Penelitian Chen (2013), Yeibo (2012), dan Galita (2011) memiliki persamaan dengan penelitian ini yaitu pada pendekatan yang digunakan, dalam hal ini pendekatan stilistika. Meskipun, pada aspek stilistika yang dianalisis terdapat perbedaan yaitu penelitian Chen memanfaatkan aspek leksikal, irama, sajak, dan pola kalimat, sedangkan Yeibo memanfaatkan bahasa kiasan sebagai penanda semantik, dan Galita memanfaatkan aspek fonetis, morfologis, sintaksis, leksikal, dan semantic. Sementara itu untuk penelitian peneliti memanfaatkan aspek diksi, gaya bahasa, dan citraan. Perbedaan lainnya adalah jenis teks sastra yang digunakan. Penelitian ini berupaya untuk mengkaji empat cerita anak Indonesia Si Bungsu Katak, Si Molek, Masarasenani dan Matahari, dan Si Kecil karya Murti Bunanta

\section{METODE}

Penelitian ini menggunakan deskriptif analisis dengan cara mendeskripsikan fakta-fakta yang kemudian disusul dengan analisis. Analisis menggunakan pendekatan stilistika yang mementingkan kesatuan konstruksi cerita dengan tema yang disampaikan. Elemen yang diperhatikan dan diperiksa adalah diksi, gaya bahasa, dan citraan. Diksi sebagai pilihan katakata yang dilakukan oleh pengarang dalam karyanya guna menciptakan efek makna tertentu. Gaya bahasa (Figurative Language) merupakan bentuk retorik, yaitu penggunaan kata-kata dalam berbicara dan menulis untuk meyakinkan atau mempengaruhi pembaca. Dalam hubungannya antara bahasa dan gaya bahasa, gaya bahasa dianggap sebagai bagian dari bahasa. Citraan atau pengimajian (imagery) merupakan kata atau susunan kata yang dapat mengungkapkan pengalaman sensoris, seperti penglihatan, pendengaran, dan perasaan.

\section{HASIL DAN PEMBAHASAN}

Berdasarkan pendahuluan yang telah didefinisikan di atas, keempat buku yang dianalisis kali ini menunjukkan beberapa hal menarik sebagai berikut.

a. Si Bungsu Katak (1998) cerita rakyat ini berasal dari kepulauan Kei yang terletak di 
Maluku Tenggara merupakan buku sastra anak (dwibahasa - Indonesia dan Inggris) yang ditulis oleh Murti Bunanta, buku ini mendapatkan hadiah internasional dari Poland, The Janusz. Korzcak International Literary Prize. Judul buku ini sudah menjelaskan kisah di dalamnya. Tentang Si Bungsu Katak yang merupakan anak bungsu dari tujuh bersaudara yang memiliki sifat memaafkan, dan mandiri. Hal ini terlihat bagaimana Si Bungsu Katak memaafkan ibu yang memperoloknya dan saudara-saudaranya yang telah meninggalkan serta menghinanya. Sifat mandirinya membuat Si Bungsu Katak dapat bertahan hidup ketika di tinggal sendiri dalam sebuah pulau. Dia memilih mendirikan pondok dan berladang sesuai dengan kemampuan atau pengetahuan yang dimiliki ketika masih tinggal di rumah. Si Bungsu Katak juga termasuk dalam komunikatif karena mampu berdialog dengan ibu, saudara-saudaranya, raja, putri, dan raksasa untuk memecahkan masalah yang ada dan menciptakan sesuatu yang berguna bagi sekitarnya. Cerita serupa berasal dari daerah lain seperti Joko Kendil dari Jawa dan Tjereta Barakai dari pulau Madura. Cerita anak semacam ini didalam daftar Motif Indeks Stith Thompson bernomor L 112. Hero (Heroine) of Unpromising Appearance. Tokoh lelaki atau perempuan yang tidak berpengharapan karena wajah yang tidak menguntungkan.

b. Si Molek (2001) dongeng ini berasal dari Riau. Buku ini menceritakan tentang sepasang suami istri yang memiliki tujuh orang anak perempuan memiliki wajah cantik, tetapi yang paling cantik adalah si bungsu yang diberi nama Si Molek. Si Molek menikah dengan seekor ikan Jerawan yang merupakan seorang pemuda gagah perkasa bernama Tanara. Hal ini yang membuat kakak-kakak dari si Molek menjadi iri hati dan dengki. Hal ini berakibat saudara-saudara Si Molek ingin mencelakai dia tetapi berhasil diselamatkan oleh suaminya Tanara. Si Molek pun memaafkan saudara-saudaranya dan mereka pada akhirnya hidup bahagia semua. Kesamaan cerita dari daerah lain seperti Lutung Kasarung dari Jawa Barat dan Tattadu dari Sulawesi Selatan. Cerita semacam ini di dalam daftar Motif-Indeks Stith Thompson bernomor L112. Hero (Heroine) of Unpromosing Appearance. Tokoh lelaki atau perempuan yang tidak berpengharapan karena wajah yang tidak menguntungkan.

c. Cerita "Masarasenani dan Matahari" (2001) cerita rakyat ini berasal dari papua. Buku ini menceritakan tentang sepasang suami istri yang memiliki dua anak perempuan yang setiap hari menokok sagu untuk kebutuhan hidup. Mereka menderita kalaparan karena matahari tidak adil membagi siang dan malam, sehingga Maserasenani ingin menjerat matahari. Usahanya pun berhasil dan matahari memperbaiki sifatnya karena mendengarkan cerita dari Maserasenani.

d. Cerita "Si Kecil" (2001) cerita ini berasal dari Sulawesi Selatan, mendapatkan penghargaan dalam USBBY Outstanding International Books (OIB) List 2014 di Amerika. Menceritakan tentang suami istri yang memiliki tujuh orang anak lelaki. Pada suatu hari mereka mendapatkan bencana sehingga jatuh dalam kemiskinan. Untuk menyelamatkan nyawa, mereka membuang empat (4) anak tertua ke dalam hutan, salah satunya anak sulung (Si Kecil). Mendapatkan nama Si Kecil karena kondisi fisik terkecil dari semua saudara-saudaranya. Mereka bertahan hidup di dalam hutan dan berhasil mengalahkan seorang raksasa pemakan manusia dan membawa pulang harta benda untuk keluarganya. Hal ini dapat terjadi karena kreatif, komonukatif dan kerja keras $\mathrm{Si}$ Kecil. Cerita serupa lainnnya yang ditemukan di daerah lain adalah Senggutru dari Jawa dan Putri Bunga Melur dari Sumatera Utara. Cerita semacam ini dalam daftar Motif-Indeks Stith Thompson bernomor L 311. Weak (small) overcomes large fighter. Tokoh yang lemah (kecil) mengalahkan lawan yang besar, dan nomor G 520. Ogre deceived into self-injury. Raksasa diperdayakan sehingga melukai dirinya sendiri.

\section{1. Diksi}

Diksi merupakan pilihan kata yang digunakan oleh pengarang dalam menyampaikan pemikirannya. Di dalam sastra anak Si Bungsu Katak, Si Molek, Masarasenani dan Matahari, dan Si Kecil karya Murti Bunanta, 
diksi digunakan untuk membantu pembaca memahami maksud yang ingin disampaikan pengarang. Diksi juga digunakan untuk mengongkretkan penjelasan pengarang. Diksi yang ditemukan dalam sastra anak Si Bungsu Katak, Si Molek, Masarasenani dan Matahari, dan Si Kecil karya Murti Bunanta meliputi kata denotasi, kata konotatif, kata sapaan khas, dan kata konkret.

Kata denotasi adalah kata yang mengacu atau menunjuk pengertian atau makna yang sebenarnya. Kata denotasi merupakan makna yang sesuai dengan makna atau pengertian yang sebenarnya sesuai dengan makna kamus (harfiah), biasanya disebut makna konseptual. Berikut kutipan yang menunjukkan adanya kata denotasi.

\section{"Seorang raksasa mengendap-endap mendekati pondok si Bungsu Katak." (Bunanta, 2011,p. 9a)}

Dalam kamus besar bahasa Indonesia (KBBI) 'mengendap-endap' memiliki arti membungkuk-bungkuk agar tidak kelihatan; sembunyi-sembunyi. Dalam cerita Si Bungsu Katak menceritakan seorang raksasa yang mendekati pondok untuk mengambil waluh yang ditanam oleh Si Bungsu Katak. Kata 'mengendap-endap' memiliki pengertian yang sesuai dengan makna kamus.

Kata konotatif merupakan hal penting yang digunakan pengarang dalam menciptakan suatu karya sastra, karena penggunaan kata konotatif di dalam karya sastra dapat menimbulkan efek estetis. Di dalam sastra anak Si Bungsu Katak, Si Molek, Masarasenani dan Matahari, dan Si Kecil karya Murti Bunanta ditemukan kata konotatif. Kata konotatif tersebut kebanyakan digunakan dalam penarasian hati tokoh, pendeskripsian suasana, dan penyebutan tempat atau orang. Kata konotatif dapat dilihat pada kutipan di bawah ini.

"Dilihatnya si Bungsu Katak
menanggalkan kulit kataknya."
(Bunanta, 201,p.31a)

Kata 'menanggalkan' dalam kamus besar bahasa Indonesia (KBBI) memiliki arti membuka (pakaian dan sebagainya); melepaskan; menjadikan (menyebabkan) tanggal. Kata menanggalkan dalam cerita $\mathrm{Si}$ Bungsu Katak ditambahkan keterangan kulit, sehingga memiliki pengertian berubah wujud. Perubahan dari seekor katak menjadi manusia, bukan melepaskan pakaian.

Kata sapaan khas merupakan kata yang digunakan untuk menyapa atau menyebut seseorang secara khusus. Di dalam sastra anak Si Bungsu Katak karya Murti Bunanta ditemukan kata sapaan khas digunakan untuk menamai tokoh. Kata sapaan khas dapat dilihat pada kutipan di bawah ini.

"Oleh karena itu, ia dipanggil si Bungsu katak." (Bunanta, 2011,p. 1a)

Kata "Bungsu Katak" merupakan penggabungan dari kata 'bungsu' yang memiliki arti anak terakhir, sedangkan 'katak' adalah nama hewan. Panggilan "Bungsu Katak" terjadi karena tokoh merupakan anak terakhir dan memiliki wujud katak sehingga memiliki kata sapaan khas untuk menunjukkan keunikannya.

Kata konkret merupakan kata yang melukiskan keadaan atau peristiwa yang menyebabkan pembaca seorang dapat mendengar, melihat, dan merasakan pendeskripsian pegarang melalui cerita. Kata konkret dalam sastra anak Si Bungsu Katak karya Murti Bunanta dimanfaatkan pengarang dalam mendeskripsikan peristiwa atau keadaan yang di alami tokoh. Kata konkret secara langsung memberikan pemahaman kepada pembaca apa yang dimaksudkan oleh penulis. Pemanfaatan kata konkret dapat dilihat pada kutipan di bawah ini.

"Untuk memenuhi kebutuhan
sekeluarga, anak-anaknya setiap hari
membantu mencari kayu bakar
untuk dijual dan mengumpulkan
buah-buahan di hutan untuk
dimakan." (Bunanta, 2010,p. 1d)

Kata 'kayu bakar' dan 'buah-buahan' merupakan kata yang melukiskan benda. Benda-benda tersebut bisa dideskripsikan pengarang melalui cerita sehingga pembaca 
memiliki imajinasi tentang apa yang dimaksudkan oleh pengarang.

\section{2. Gaya Bahasa}

Gaya bahasa merupakan bentuk kebahasaan yang memiliki makna kias atau makna tidak langsung. Penggunaan gaya bahasa digunakan pengarang untuk menimbulkan imajinasi dan asosiasi pembaca. Aspek gaya bahasa yang dianalisis dalam sastra anak Si Bungsu Katak, Si Molek, Masarasenani dan Matahari, dan Si Kecil karya Murti Bunanta adalah asidenton, personifikasi, satire, sarkasme, antithesis, polisidenton, kontrakdiksi interminus, paralelisme, tautologi, repetisi, hiperbola, innuendo, interupsi, litotes, dan inversi.

Asidenton adalah sebuah gaya bahasa yang menggambarkan penegasan dengan menyatakan beberapa hal, benda, atau suatu keadaan secara berturut-turut tanpa menggunakan kata sambung. Gaya bahasa personifikasi dipergunakan untuk melukiskan sesuatu benda, barang, organ, atau apapun yang dianggap dapat berperilaku sebagai manusia. Gaya bahasa satire adalah gaya bahasa untuk menyatakan sindiran terhadap suatu keadaan atau seseorang. Gaya bahasa sarkasme merupakan gaya bahasa yang menggunakan kata-kata kasar atau tidak sopan. Gaya bahasa antithesis adalah gaya bahasa yang mengandung gagasan yang bertentangan dengan mempergunakan pasangan kata-kata yang berlawanan.

Gaya bahasa polisidenton adalah suatu gaya yang hampir sama dengan asindenton. Gaya bahasa kontrakdisi interminus adalah gaya bahasa pernyataan yang bersifat menyangkal yang telah disebutkan pada bagian sebelumnya. Gaya bahasa pararelisme adalah semacam gaya bahasa yang baik untuk menonjolkan kata atau kelompok kata yang sama fungsinya dalam kalimat. Gaya bahasa tautologi adalah gaya bahasa pengulangan kata, gagasan, atau pernyataan dengan menggunakan sinominnya. Gaya bahasa repetisi adalah gaya bahasa yang menggunakan perulangan bunyi, suku kata, kata, atau bagian kalimat yang dianggap penting untuk memberi tekanan dalam sebuah cerita.
Gaya bahasa hiperbola merupakan gaya bahasa yang melukiskan peristiwa secara berlebihan. Gaya bahasa innuendo adalah sindiran yang bersifat mengecilkan fakta sesungguhnya. Gaya bahasa interupsi ungkapan berupa penyisipan keterangan tambahan di antara unsur-unsur kalimat. Gaya bahasa litotes dipakai untuk melukiskan hal sekecil-kecilnya untuk merendahkan diri. Gaya bahasa inversi menyebutkan terlebih dahulu predikat dalam suatu kalimat sebelum subjeknya. Berikut beberapa kutipan mengenai gaya bahasa yang terdapat dalam keempat cerita anak.

"Dilihatnya si Jerawan berjalan dengan gagah menuju pantai. Di sana ia menaiki sebuah perahu layar miliknya. Segera, dengan perahu layar itu jerawan menuju ke tengah laut bergabung dengan nelayan-nelayan yang lain. Rupanya setiap pagi ketika pergi berlayar suami si Molek berubah menjadi pemuda tampan. Sorenya, setelah menjual hasil tangkapannya, ia kembali ke hutan dan pulang ke rumah sebagai seekor jerawan. Si Molek menyimpan rahasia suaminya rapatrapat. Ia tidak mengatakan pada siapa pun dan bermaksud menyelidiki terlebih dahulu. Begitulah, berhari hari setiap pagi, dengan diam-diam ia mengikuti suaminya dan menyaksikan suaminya berubah menjadi pemuda tampan. Akhirnya, si Molek mencari akal supaya si Jerawan tidak lagi berubah menjadi seekor ikan." (Bunanta, 2012,p. 17b)

"Ketika itulah si Sulung berkata dengan dengki, "Hai Molek, tinggallah kau seorang diri di sini. Kau tidak patut mendapatkan suami segagah dan setampan Tanara. Akulah yang patut menjadi isterinya. Adalah sebuah kesalahan saudara terbungsu mendapatkan kehormatan seperti ini." (Bunanta, 2012,p. 27b)

"Ada perhiasan emas, ada perak dan ada pula permata serta intan berlian 
yang indah-indah.” (Bunanta, 2010,p.

$33 d)$

Data (1) menunjukkan gaya bahasa asidenton dalam cerita Si Molek karya Murti Bunanta. keadaan bagaimana suaminya berubah menjadi seorang pemuda tampan dan penegasan tentang bagaimana cara dia mencari nafkah. Perubahan menjadi seorang pemuda tampan dengan cara melepaskan kulit jerawannya pagi hari ketika ingin melaut menjadi nelayan dan ketika kembali dari melaut, dia menggunakan kembali kulit jerawannya. Sementara untuk penegasan bagaimana dia mencari nafkah dengan rincian Jerawan berjalan dengan gagah, menaiki perahu layar miliknya sendiri, ke tengah laut dan bergabung dengan nelayan lainnya.

Gaya bahasa sarkasme terdapat pada data (2). Pada cerita Si Molek sindiran yang dilakukan oleh si Sulung kepada si Molek karena dia menikah dengan Tanara yang sekarang berwujud gagah dan tampan. Si sulung dan kakak-kakaknya yang lain tidak rela si Molek mendapatkan suami yang gagah dan tampan sehingga mereka berencana untuk mencelakainya.

Rincian data (51) merupakan gaya bahasa repetisi yang terdapat pada cerita anak Si Kecil karya Murti Bunanta. menunjukkan kata 'ada' yang mengalami perulangan menegaskan dan menekankan apa saja yang terdapat dalam peti yang dimiliki oleh raksasa yaitu emas, perak, permata. Kata 'ada' dalam kamus besar bahasa Indonesia berarti keberadaan harta benda tersebut dalam peti.

\section{3. Citraan}

Citraan adalah sebuah pengalaman keinderaan dalam berimajinasi sehingga pembaca seolah-olah melihat, mendengar, dan merasakan sesuatu yang dihasilkan oleh katakata. Dengan demikian citraan dalam karya sastra untuk membantu pembaca seakan-akan ikut merasakan peristiwa yang digambarkan pegnarang melalui imaji-imaji yang ditimbulkan lewat kata-kata. Dalam sastra anak Si Bungsu Katak, Si Molek, Masarasenani dan Matahari, dan Si Kecil karya Murti Bunanta terdapat 5 (lima) citraan yaitu citraan penglihatan, citraan pendengaran, citraan gerak, citraan perabaan, dan citraan pengecapan.

Citraan penglihatan (Visual Imagery) adalah citraan yang timbul oleh penglihatan. Citraan visual dapat mengusik indera penglihatan pembaca sehingga akan membangkitkan imajinasinya untuk memahami karya sastra. Citraan pendengaran (Auditory Imagery) merupakan citraan yang ditimbulkan oleh pendengaran. Di samping itu, citraan pendengaran akan lebih mudah melukiskan keadaan untuk merangsang imaji pembaca dalam mencapai efek estetis.

Citraan gerak (Kinesthetuc Imagery) merupakan citraan yang melukiskan sesuatu yang sesungguhnya tidak bergerak tetapi dilukiskan sebagai dapat bergerak ataupun gambaran gerak umumnya. Citraan perabaan (tactile Imagery) merupakan citraan yang ditimbulkan melalui perabaan. Biasanya, citraan perabaan digunakan untuk menghidupkan imaji pembaca dalam memahami karya sastra sehingga timbul efek estetis. Citraan pencecapan merupakan pelukisan imajinasi yang dihasilkan oleh pengalaman indera pencecapan dalam hal ini lidah. Berikut beberapa contoh kutipan citraan yang terjadi dalam keempat cerita anak tersebut.

"Orang-orang terheran-heran melihat kedatangan seorang kesatria gagah dan tampan.” (Bunanta, 2011,p. 25a)

"Mendengar cerita dan keluhan Masarasenani, matahari berjanji akan merubah sifatnya." (Bunanta, 2011,p. 31c)

"Setelah berkata demikian, cepat-cepat mereka mengayuh sampannya kembali ke pantai dan meninggalkan si Molek tak berdaya seorang diri." (Bunanta, 2012,p. 27b)

Data (1) terdapat pada cerita Si Bungsu Katak karya Murti Bunanta merupakan citraan penglihatan. Kata 'melihat' jelas menunjukkan penglihatan orang-orang akan kedatangan seorang kesatria, dan kata 'gagah dan tampan' merupakan penjelasan apa yang dilihat oleh orang-orang. 
Data (2) terdapat pada cerita Masarasenani dan Matahari karya Murti Bunanta merupakan citraan pendengaran. Kata 'mendengar' menjelaskan pendengaran yang dialami oleh matahari akan cerita dan keluhan Masarasenani. Data (3) terdapat pada cerita Si Molek karya Murti Bunanta merupakan citraan gerak. Kata 'mengayuh' memiliki arti mendayung dalam kamus besar bahasa Indonesia (KBBI).

Mengacu pada hasil analisis aspek diksi dapat diketahui bahwa aspek diksi dalam Tabel 1: Persentase Diksi sastra anak Si Bungsu Katak, Si Molek, Masarasenani dan Matahari, dan Si Kecil karya Murti Bunanta sangat variatif meliputi kata denotasi, kata denotatif, kata sapaan khas, dan kata konkret. Pemanfaatan tiap-tiap aspek diksi digunakan pengarang untuk menimbulkan efek estetis sehingga pesan yang diinginkan pengarang dapat tercapai. Berikut ini data disajikan mengenai hasil analisis diksi yang terdapat dalam sastra anak Si Bungsu Katak, Si Molek, Masarasenani dan Matahari, da Si Kecil karya Murti Bunanta.

\begin{tabular}{|c|c|c|c|c|}
\hline No & Aspek Diksi & $\begin{array}{c}\text { Frekuensi } \\
\text { Penggunaan } \\
\text { Data (x) } \\
\end{array}$ & $\begin{array}{c}\text { Frekuensi } \\
\text { Relatif } \mathrm{X} / \sum \mathrm{x}\end{array}$ & $\begin{array}{c}\text { Frekuensi } \\
\text { Absolut/Presentasi } \\
\mathrm{X} / \sum \mathrm{x} \text { x } 100 \% \\
\end{array}$ \\
\hline 1 & Kata Denotasi & 49 & 0.5384 & $53.85 \%$ \\
\hline 2 & Kata Konotatif & 9 & 0.0989 & $9.89 \%$ \\
\hline 3 & Kata Sapaan Khas & 4 & 0.0439 & $4.40 \%$ \\
\hline \multirow[t]{2}{*}{4} & Kata Konkret & 29 & 0.3186 & $31.87 \%$ \\
\hline & Jumlah & 91 & 1 & $100 \%$ \\
\hline
\end{tabular}

Berdasarkan tabel presentase diksi di atas, dapat diketahui penggunaan diksi yang dominan dan yang minim digunakan pengarang dalam sastra anak Si Bungsu Katak, Si Molek, Masarasenani dan Matahari, da Si Kecil karya Murti Bunanta. Diksi yang dominan terlihat pada kata denotasi dengan jumlah 49 data atau presentase $53,85 \%$. Pemanfaatan diksi yang sedikit dapat terlihat pada kata sapaan khas dengan jumlah 4 data atau $4.40 \%$.

Ada 4 jenis diksi yang digunakan dalam keempat buku Murti Bunanta yang diteliti. Diksi merupakan pilihan kata yang digunakan pengarang dalam menciptakan karyanya. Kekhasan pilihan kata tersebut menyebabkan setiap karya memiliki kekuatan tersendiri dalam menyampaikan suatu pesan. $\mathrm{Hal}$ ini sesuai dengan data diksi yang ditemukan, penggunaan pilihan kata denotasi yang dominan dalam setiap karya sastra anak yang diteliti bertujuan untuk menyampaikan pesan secara langsung sehingga pembaca (anak-anak) dapat dengan mudah memahaminya. Pemilihan kata konkret untuk menggambarkan peristiwa yang menyebabkan pembaca dapat mendengar, melihat, dan merasakan pendeskripsian pengarang melalui cerita. Penggunaan kata konotatif jarang digunakan oleh pengarang karena target dari tulisan berupa pembaca anak-anak, dan penggunaan kata sapaan khas dilakukan untuk penokohan, atau judul buku secara langsung.

Berdasarkan hasil analisis gaya bahasa dapat diketahui gaya bahasa dalam sastra anak Si Bungsu Katak, Si Molek, Masarasenani dan Matahari, dan Si Kecil Karya Murti Bunanta sangat variatif meliputi asidenton, personifikasi, satire, sarkasme, antithesis, polisidenton, kontrakdisi interminus, paralelisme, tautologi, repetisi, hiperbola, innuendo, interpusi, litotes, dan inversi. Pemanfaatan tiap-tiap gaya bahasa sastra anak Si Bungsu Katak, Si Molek, Masarasenani dan Matahari, dan Si Kecil Karya Murti Bunanta digunakan pengarang untuk menyampaikan imajinasi dan asosiasi pengarang. Sehingga cerita bisa sampai dengan baik untuk pembaca. Berikut ini disajikan mengenai hasil analisis gaya bahasa yang terdapat dalam sastra anak Si Bungsu Katak, Si Molek, Masarasenani dan Matahari, dan Si Kecil Karya Murti Bunanta. 
Tabel 2: Persentase Aspek Majas

\begin{tabular}{rlrcr}
\hline No & Aspek Gaya Bahasa & $\begin{array}{c}\text { Frekuensi } \\
\text { Penggunaan } \\
\text { Data }(\mathrm{x})\end{array}$ & $\begin{array}{c}\text { Frekuensi } \\
\text { Relatif } \\
\mathrm{X} / \sum \mathrm{x}\end{array}$ & $\begin{array}{c}\text { Frekuensi } \\
\text { Absolut/Presentasi } \\
\mathrm{X} / \sum \mathrm{x} \text { x 100\% }\end{array}$ \\
\hline 1 & Asidenton & 16 & 0.2581 & $25.8 \%$ \\
2 & Personifikasi & 13 & 0.2097 & $21.0 \%$ \\
3 & Satire & 1 & 0.0161 & $1.6 \%$ \\
4 & Sarkasme & 2 & 0.1290 & $12.9 \%$ \\
5 & Antitesis & 2 & 0.0323 & $3.2 \%$ \\
6 & Polisidenton & 3 & 0.0484 & $4.8 \%$ \\
7 & Kontradiksi Interminus & 1 & 0.0161 & $1.6 \%$ \\
\hline 8 & Paralelisme & 1 & 0.0161 & $1.6 \%$ \\
\hline 9 & Tautologi & 4 & 0.0645 & $6.5 \%$ \\
\hline 10 & Repetisi & 2 & 0.0323 & $3.2 \%$ \\
\hline 11 & Hiperbola & 5 & 0.0806 & $3.1 \%$ \\
\hline 12 & Innuendo & 2 & 0.0323 & $3.2 \%$ \\
\hline 13 & Interupsi & 1 & 0.0161 & $1.6 \%$ \\
\hline 14 & Litotes & 1 & 0.0161 & $3.6 \%$ \\
\hline 15 & Inversi & 2 & 0.0323 & $100 \%$ \\
\hline & Jumlah & 62 & 1 & \\
\hline
\end{tabular}

Tabel presentase gaya bahasa di atas, menunjukkan perihal penggunaan gaya bahasa yang dominan dan yang minim digunakan oleh pengarang dalam sastra anak Si Bungsu Katak, Si Molek, Masarasenani dan Matahari, dan Si Kecil Karya Murti Bunanta. Penggunaan gaya bahasa yang dominan dapat terlihat pada gaya bahasa asidenton dengan jumlah 16 data atau presentase 25,8\%. Pemanfaatan gaya bahasa paling minimal dapat terlihat pada gaya bahasa satire dengan jumlah 1 data atau presentase $1,6 \%$, gaya bahasa kontrakdisi interminus dengan jumlah 1 data atau presentase $1,6 \%$, gaya bahasa paralelisme dengan jumlah 1 data atau presentase 1,6\%, gaya bahasa interupsi dengan jumlah 1 data atau presentase $1,6 \%$, dan gaya bahasa litotes dengan jumlah 1 data atau presentase 1,6\%.

Terdapat 15 (lima belas) jenis gaya bahasa yang digunakan dalam keempat buku Murti Bunanta yang diteliti. Penggunaan gaya bahasa asidenton dominan digunakan untuk menggambarkan penegasan dengan menyatakan beberapa hal, benda, atau suatu keadaan secara berturu-turut tanpa kata sambung. Hal ini dilakukan untuk menguatkan imajinasi pembaca. Terdapat beberapa majas yang jarang digunakan oleh pengarang seperti satire, kontradkisi interminus, paralelisme, interupsi dan litotes.

Berdasarkan hasil analisis aspek citraan dapat diketahui bahwa aspek citraan dalam sastra anak Si Bungsu Katak, Si Molek, Masarasenani dan Matabari, dan Si Kecil Karya Murti Bunanta sangat variatif meliputi citraan penglihatan, citraan pendengaran, citraan gerak, citraan perabaan, dan citraan pengecapan. Pemanfaatan tiap-tiap aspek citraan dalam sastra anak Si Bungsu Katak, Si Molek, Masarasenani dan Matahari, dan Si Kecil Karya Murti Bunanta digunakan pengarang untuk menimbulkan efek estetis sehingga pesan yang ingin disampaikan pengarang dapat tercapai. Berikut ini disajikan mengenai hasil analisis aspek citraan yang terdapat di dalamnya. 


\begin{tabular}{|c|c|c|c|c|}
\hline No & Aspek Citraan & $\begin{array}{c}\text { Frekuensi } \\
\text { Penggunaan } \\
\text { Data }(\mathrm{x})\end{array}$ & $\begin{array}{c}\text { Frekuensi Relatif } \\
\mathrm{X} / \sum \mathrm{x}\end{array}$ & $\begin{array}{c}\text { Frekuensi } \\
\text { Absolut/Presentasi } \\
\mathrm{X} / \sum \mathrm{x} \times 100 \%\end{array}$ \\
\hline 1 & Citraan Penglihatan & 27 & 0.3698 & $36.99 \%$ \\
\hline 2 & Citraan Pendengaran & 16 & 0.2191 & $21.92 \%$ \\
\hline 3 & Citraan Gerak & 26 & 0.3561 & $35.62 \%$ \\
\hline 4 & Citraan Perabaan & 3 & 0.0410 & $4.11 \%$ \\
\hline \multirow[t]{2}{*}{5} & Citraan Pengecapan & 1 & 0.0136 & $1.37 \%$ \\
\hline & Jumlah & 73 & 1 & $100.00 \%$ \\
\hline
\end{tabular}

Berdasarkan tabel presentase aspek citraan di atas, dapat diketahui bahwa penggunaan citraan yang dominan dan minim yang digunakan oleh pengarang. Penggunaan citraan yang dominan atau banyak dapat terlihat pada citraan penglihatan dengan jumlah 27 data atau presentase 36,99\%. Pengunaan citraan yang minum atau sedikit dapat terlihat pada citraan pengecapatan dengan jumlah 1 data atau 1,37\%

Terdapat 5 jenis citraan dalam keempat karya Murti Bunanta yang diteliti. Aspek citraan penglihatan, pendengaran, dan gerak banyak ditemukan karena hal ini memudahkan pembaca anak-anak memahami isi cerita dan membantu mereka dalam berimajinasi. Hal ini sejalan dengan penelitian yang dilakukan oleh Bilal \& Cheema (2012,p.33) dengan judul "Stylistic Analysis of Wordsworth's Poem: EarlySpring" perihal pemanfaatan stilistika puisi Early Spring karya Willian Wordsworth. Penelitian ini meneliti puisi, dan bertujuan untuk menginterpretasikan penyimpangan sintaksis dan semantic yang dilakukan oleh Wordsworth. Hasil penelitian ini membantu dalam memahami konsep dasar puisi yang kotras antara keharmonisan alam dan ketidakharmonisan umat manusia. Persamaan penelitian Bilal \& Cheema dengna penelitian ini adalah sama-sama menelaah kajian stilistika. Namun ada perbedaan dalam fokus permasalahan penelitian. Bilal \& Cheema menelaah pemanfaatan stilistika puisi Early Spring yang mengkaji penyimpangan stilistika dan semantic yang dilakukan oleh Wordsworth, sedangkan penelitian ini focus terletak pada pemanfaatan stilistika cerita anak Si Bungsu Katak, Si Molek, Masarasenani dan Matahari, dan Si Kecil karya Murti Bunanta yang menyoroti pemanfaatan diksi, gaya bahasa dan citraan.

\section{SIMPULAN}

Berdasarkan hasil analisis data dapat disimpulkan bahwa keempat cerita anak $S i$ Bungsu Katak, Si Molek, Masarasenani dan Matahari, dan Si Kecil karya Murti Bunanta terdapat diksi, gaya bahasa, dan citraan. Diksi yang dominan terlihat pada kata denotasi dengan jumlah 49 data atau presentase $53,85 \%$. Pemanfaatan diksi yang sedikit dapat terlihat pada kata sapaan khas dengan jumlah 4 data atau 4,40\%. Penggunaan denotasi lebih dominan karena target pengarang adalah anak-anak sehingga menggunakan diksi denotasi untuk pemilihan kata sesuai dengan makna sebenarnya (harfiah). Kata sapaan khas terdapat paling sedikit tetapi terdapat pada seluruh buku yang diteliti, hal ini karena kata sapaan khas digunakan untuk menandai secara khusus tokoh utama bahkan judul dari cerita tersebut, walaupun sedikit kata sapaan khas terdapat pada semua buku cerita anak. Gaya bahasa yang dominan dapat terlihat pada gaya bahasa asidenton dengan jumlah 16 data atau presentase 25,8\%. Pemanfaatan gaya bahasa paling minimal dapat terlihat pada gaya bahasa satire dengan jumlah 1 data atau presentase $1,6 \%$, gaya bahasa kontrakdisi interminus dengan jumlah 1 data atau presentase 1,6\%, gaya bahasa paralelisme dengan jumlah 1 data atau presentase $1,6 \%$, gaya bahasa interupsi dengan jumlah 1 data atau presentase 1,6\%, 
dan gaya bahasa litotes dengan jumlah 1 data atau presentase $1,6 \%$. Gaya bahasa asidenton menggambarkan penegasan dengan menyatakan beberapa hal, benda, atau suatu keadaan secara berturut-turut tanpa menggunakan kata sambung. Hal ini untuk memudahkan pembaca menerima imajinasi yang dimaksudkan oleh pengarang. Banyaknya jenis gaya bahasa yang terdapat menunjukkan kekayaan gaya bahasa yang digunakan. Citraan yang dominan atau banyak dapat terlihat pada citraan penglihatan dengan jumlah 27 data atau presentase 36,99\%. Pengunaan citraan yang minum atau sedikit dapat terlihat pada citraan pengecapan dengan jumlah 1 data atau 1,37\%. Perasaan estetis akan lebih mudah terangsang melalui citraan penglihatan. Selain itu, dalam karya sastra pengarang melukiskan karakter tokoh, melukiskan keadaan tempat, pemandangan, atau bangunan dalam menciptakan citraan penglihatan.

\section{DAFTAR RUJUKAN}

Bilal, H. A. \& Cheema, A. (2012). Stylistic Analysis of Wordsworth's Poem: EarlySpring. British Journal of Humanities and Social Sciences, 5 (2), 25-34.

Bunanta, M. (2010). Si Kecil "Tiny Boy". Jakarta: Grasindo.

------. (2011). Si Bungsu Katak "The Youngest Frog”. Jakarta: Grasindo.

(2011). Masarasenani dan Matahari. Jakarta: Grasindo.

Grasindo.

(2012). Si Molek. Jakarta:

Chen, Q. (2013). Analysis on Three Versions of If by Life You Were Deceived from Perspective of Stylistics. Journal of
Language Teaching and Research, 4 (3), 598-604.

Galita, R. (2011). A Pragma-Stylistic Approach on Deixis. LiBRI. Linguistic and Literary Broad Research and Innovation, 2 (1), 36-50.

Nurgiyantoro, B. (2007). Teori Pengkajian Fiksi. Yogyakarta. Gadjah Mada University Press.

Ratna, N.K. (2016). Stilistika: Kajian Puitika Bahasa, Sastra, dan Budaya. Yogyakarta: Pustaka Pelajar.

Sarumpaet, R.K.T. (1976). Bacaan Anak-anak. Jakarta: Pustaka Jaya.

(2010). Pedoman Penelitian Sastra Anak. Jakarta: Yayasan Pustaka Obor Indonesia.

Satoto, S. (2012). Stilistika. Surakarta: STSI Press.

Thompson, S. (1955). Motif - Index of Folk Literature: A Classification of Narrative Elements in Folktales, Ballands, Myths, Fables, Mediaeval Romances Exempla, Fabliaux, Jest-Books and Local Legends. Indiana: Indiana University Press.

Yeibo. E. (2012). Figuratif Language and Stylistic Function J. P. ClarkBekederomo's Poetry. Journal of Language Teaching and Research, 3 (1), 180-187.

\section{UCAPAN TERIMA KASIH}

Peneliti mengucapkan terima kasih kepada semua pihak yang telah banyak membantu dalam penulisan artikel ini, terutama kepada Prof. Sahid Teguh Widodo, M.Hum., Ph. D., dan Dr. Slamet Subiyantoro, M.Si., yang telah membimbing dalam penyusunan artikel ini. 